ISSN: 2224-0616

Int. J. Agril. Res. Innov. \& Tech. 7 (1): 14-20, J une, 2017

Available online at http:/ / www.ijarit.webs.com

\title{
MONTHLY AND DIURNAL VARIATIONS OF LIMNOLOGICAL CONDITIONS OF TWO PONDS
}

\author{
A.K.M. Fazlur Rahaman', M.A. Mansur ${ }^{2 *}$ and M. Shahidur Rahman ${ }^{3}$
}

Received 29 January 2017, Revised 18 May 2017, Accepted 26 June 2017, Published online 30 June 2017

\begin{abstract}
A study on monthly and diurnal changes of limnological conditions of two ponds was conducted in the Bangladesh Agricultural University campus, Mymensingh. The research work was performed by studying the limnological parameters such as transparency, temperature, dissolved oxygen, free carbon dioxide, $\mathrm{pH}$, total alkalinity, nitrate-nitrogen, phosphate-phosphorus and plankton. Diurnal variations of physico-chemical factors were studied fortnightly at $6 \mathrm{hrs}$ intervals at 6 a.m., 12 noon, 6 p.m. and 12 midnight. The amounts of transparency, dissolved oxygen and $\mathrm{pH}$ were higher during winter months than in summer months in both the ponds. Transparency, water temperature, total alkalinity, $\mathrm{NO}_{3}-\mathrm{N}$ and $\mathrm{PO}_{4}-\mathrm{P}$ were higher during summer months than in winter months in both the ponds. But the amount of free carbon dioxide was higher during winter months than in summer months in pond 1 while in pond 2 the amount of free carbon dioxide was higher during summer months than in winter months. Qualitative and quantitative monthly variations of phytoplankton and zooplankton were observed in both the ponds during the study period. The highest amount of dissolved oxygen, $\mathrm{pH}$ and total alkalinity were recorded at $6 \mathrm{p} . \mathrm{m}$. and the lowest amounts of those at $6 \mathrm{a.m}$. in both the ponds. The highest temperature was recorded at 12 noon and the lowest at 12 midnight. But the highest amount of free carbon dioxide was recorded at 6 a.m. and the lowest at 6 p.m. in both the ponds. All the factors showed appreciable diel variations throughout the study period, which indicate that the ponds are productive.
\end{abstract}

Keywords: Limnological Condition, Monthly and Diurnal Variation, Pond, Productivity

${ }^{1}$ Youth Training Centre, Department of Youth Development, Netrokona-2400, Bangladesh

${ }^{2}$ Department of Fisheries Technology, Faculty of Fisheries, Bangladesh Agricultural University, Mymensingh-2202, Bangladesh

${ }^{3}$ Department of Fisheries Management, Faculty of Fisheries, Bangladesh Agricultural University, Mymensingh-2202, Bangladesh

*Corresponding author's email: mansurft63@gmail.com (M.A. Mansur)

\section{Introduction}

Different physico-chemical factors of a water body, which determine the character and quality of biological production are very important for scientific fish culture and fisheries management. Extensive observations on diurnal variations in freshwater have been carried out in temperate regions. Successful fisheries management and scientific fish culture depend upon the various information about the diurnal variations of limnological conditions of water bodies. Some workers have made contributions to the diurnal variations of physico-chemical conditions in tropical fish ponds (Dunn, 1967; Khan et al., 1970; Michael, 1967; Philip, 1926; Reddy, 1981; Verma, 1967; Vass and Sachlan, 1953). Little information is available on the diel variations of limnological conditions of fish ponds of Bangladesh. But knowledge of diel variations of limnological conditions of ponds will be helpful for efficient fish culture practice.

\section{Materials and Methods}

\section{Description of study area}

The experiment was accomplished in two perennial ponds situated in the campus of the Bangladesh Agricultural University, Mymensingh. The ponds were arbitrarily numbered as Pond 1 and Pond 2.

\section{Estimation of limnological conditions}

Physico-chemical and biological factors of both the ponds were studied throughout the study period of 7 months. Sampling was done fortnightly. Diurnal variations of physicochemical factors were studied fortnightly at $6 \mathrm{hrs}$ intervals at 6:00 a.m., 12:00 noon, 6:00 p.m. and 12:00 midnight. 
To enumerate plankton population fourteen small samples of water (10 litre for each sample) were collected from different areas and depths of the ponds and passed through a plankton net (mesh size 55 micron). Then the collected plankton samples were preserved in $5 \%$ formalin in small plastic bottles. Plankton study was accomplished by using a Sedgewick-Rafter counting cell ( $\mathrm{S}-\mathrm{R}$ Cell) (Rahman, 1992) and under a compound binocular microscope (Olympus model BH-2). Identification of the plankton were done according to Ward and Whipple (1959), Needham and Needham (1962), Prescott (1962), Pennak (1955).

\section{Results and Discussion}

The results of monthly and diel changes of physical factors of two ponds have been presented. The surface area of two ponds, which were nearly rectangular in shape were 0.168 ha and 0.769 ha of pond 1 and pond 2, respectively. Both the ponds are perennial. The monthly transparency of water ranged from 33.00 to 45.33 $\mathrm{cm}$ and from 35.88 to $49.37 \mathrm{~cm}$ in pond 1 and pond 2 , respectively. The maximum values were recorded in the month of January and the minimum in October in pond 1 while in pond 2 the maximum was in the month of December and the minimum in October. The values of transparency were found to decrease more or less gradually with the decrease in water level. This was due to gradual increase in the amount of silt, suspended organic matter and microscopic organisms with the decrease in water level. Bamforth (1962) also reported that the transparency of water was affected by silt, microscopic organisms and suspended organic matter. The lower value during summer and higher value during winter in transparency were due to rainfall and run-off in summer and these are absent in winter.

Monthly variation in air and water temperature: The monthly variations of air temperature ranged from 18.50 to $28.88^{\circ} \mathrm{C}$. The maximum values were recorded in the month of October and the minimum values were recorded in the month of J anuary (Table 1). The monthly variations of water temperature (average of surface and bottom) ranged from 19.04 to $28.03^{\circ} \mathrm{C}$ and from 19.48 to $28.88^{\circ} \mathrm{C}$ in pond 1 and pond 2 , respectively. The maximum values were recorded in the month of April and minimum values were recorded in the month of J anuary in pond 1 while in pond 2 the maximum was in the month of April and the minimum in J anuary.
The comparatively low values of air temperature during the months of December, January and February except in November and its high values during the months of October, March and April indicate that average water temperature correlated with the air temperature. The change of temperature of air was much more rapid than that of water. During the winter months, the air temperature fell more rapidly due to cold weather and remained always below the water temperature. Similarly during summer months, air got heated more rapidly than water temperature and thus showed higher temperature than that of water in the evening. Similar observations were also recorded by Dewan (1973).

Vass and Sachlan (1953) stated that temperature of shallow and small bodies of water may follow air temperature closely with only a small variation. Ganapati (1941), Chacko and Ganapati (1949), Sitaramiah (1966) reported lowest temperature during November and December and highest temperature during April and May. The differences were comparatively very low during winter months (December and January) than the summer months (April and May). After winter months, the temperature differences between surface and bottom waters were found to increase with the increase in the differences of air temperature. This might be due to the influence of air temperature on water and due to greatly decreased volume of water.

\section{Chemical factors}

Dissolved oxygen: The results of dissolved oxygen have been presented in Table 3. The amount of dissolved oxygen showed wide variation during the period of investigation. The highest values of dissolved oxygen was $8.39 \mathrm{ppm}$ in the month of December and the minimum value was $6.99 \mathrm{ppm}$ in the month of October in pond 1 while in pond 2 the maximum value was $8.41 \mathrm{ppm}$ in J anuary and the minimum value was $7.03 \mathrm{ppm}$ in October (Tables 2 and 3). The lower concentration of dissolved oxygen as suggested by Chakrabarty et al. (1959) and Sterin et al. (1968) might be associated with rainfall and less exposure of sunlight and during the rainy season the suspended silt and organic matter carried into the pond by rain water might have reduced the dissolved oxygen content after heavy showers. In the present investigation, the data obtained that the oxygen concentration in water was inversely related to the temperature of water. Vyas and Kumar (1968), Dewan (1973) also observed the similar results. 
Table 1. Monthly variations of physical factors of water of the ponds.

\begin{tabular}{lcccccc}
\hline Month & \multicolumn{2}{c}{ Transparency $(\mathrm{cm})$} & \multicolumn{2}{c}{ Water temperature $\left({ }^{0} \mathrm{C}\right)$} & \multicolumn{2}{c}{ Air temperature $\left({ }^{0} \mathrm{C}\right)$} \\
\hline & Pond 1 & Pond 2 & Pond 1 & Pond 2 & Pond 1 & Pond 2 \\
\hline October & 33.00 & 35.85 & 27.58 & 28.20 & 28.68 & 28.68 \\
November & 39.34 & 42.44 & 22.09 & 22.54 & 22.88 & 22.88 \\
December & 43.75 & 49.39 & 19.80 & 19.82 & 18.95 & 18.95 \\
January & 45.33 & 46.50 & 19.04 & 19.48 & 18.50 & 18.50 \\
February & 41.25 & 44.56 & 22.23 & 23.91 & 22.03 & 22.03 \\
March & 34.60 & 39.75 & 28.22 & 28.28 & 27.45 & 27.45 \\
April & 36.10 & 40.65 & 28.03 & 28.88 & 27.90 & 27.90 \\
\hline Average \pm SD & $39.05 \pm 4.43$ & $42.73 \pm 4.18$ & $23.86 \pm 3.70$ & $24.42 \pm 3.72$ & $23.77 \pm 3.96$ & $23.77 \pm 3.96$ \\
\hline Range & $33.00-45.33$ & $35.85-49.39$ & $19.04-28.22$ & $19.48-28.88$ & $18.50-28.68$ & $18.50-28.68$ \\
\hline
\end{tabular}

Free carbon dioxide: The free carbon dioxide of pond 1 and pond 2 ranged from 1.60 to $3.34 \mathrm{ppm}$ and 1.10 to $2.22 \mathrm{ppm}$, respectively. The amount of free carbon dioxide was comparatively higher during the winter months (November, December and January) than the summer months (March and April) in pond 1 but the monthly variations of free $\mathrm{CO}_{2}$ in pond 2 is not distinct, the monthly values were more or less same throughout the study period. The reasons of monthly fluctuations (which are slight) of free $\mathrm{CO}_{2}$ in the ponds under the present study are not clear but higher values are associated with high temperature and high decomposition of dead organic matter and lower values are associated with low temperature and lower organic decomposition and higher rate of photosynthesis. Vyas and Kumar (1968), Sahai and Sinha (1969), Dewan (1973), Lakshminarayana (1965), Miller and Rabe (1969), Islam et al. (1974) and Dewan (1973) observed high values of free carbon dioxide in monsoon period and low values in winter months.

Hydrogen ion concentration $(\mathrm{pH})$ : The monthly variation in the values of $\mathrm{pH}$ were slight and the values found were more or less similar throughout the study period (Table 2). The higher values of $\mathrm{pH}$ in the month of December in pond 1 and in February in pond 2, which might be due to the increased rate of photosynthetic activities of phytoplankton with concomitant decrease of carbon dioxide. The increased values in $\mathrm{pH}$ might be due to the decrease of carbon dioxide and precipitation of $\mathrm{CaCO}_{3}$. Sreenivasan (1970) also stated the similar comments. The lowest $\mathrm{pH}$ values in March in pond 1 and in October in pond 2 might be associated with rainfall, high temperature and presence of high amount of free carbon dioxide. Khalaf and MacDonald (1975), Lakshminarayana (1965), Vyas and Kumar (1968) observed lower values of $\mathrm{pH}$ during monsoon. Banerjea (1967) reported that water with an almost neutral pH 6.5 to 7.5 is best suited for fish culture and average production is expected in the range of $\mathrm{pH} 6.5$ to 8.5. The values of $\mathrm{pH}$ in the present study ranged from 7.56 to 7.85 and 7.57 to 8.13 in pond 1 and pond 2, respectively that indicates the ponds are suitable for fish culture. The $\mathrm{pH}$ range of 7.5 to 8.4 indicates that the water provides optimum conditions for favourable growth of plankton (Villadolid et al. 1954). He also stated that lower $\mathrm{pH}$ values are known to adversely affect the plankton production. Swingle (1957) in his study indicated that the $\mathrm{pH}$ values varying from 6.5 - 9.0 are considered to be satisfactory. He also observed that waters with $\mathrm{pH}$ more than 9.5 were unproductive and $\mathrm{pH} 11.0$ was lethal for fish.

Total alkalinity: Total alkalinity was found to be slightly higher during summer months (March and April) than in winter months in both the ponds. The higher values of total alkalinity during March and April (summer months) and lower values of the same during October and November (winter months) of both the ponds might be due to the high rate of consumption of carbon dioxide in photosynthesis during summer months and due to low amount of consumption of carbon dioxide by short period of photosynthesis during winter months. Higher values of total alkalinity during summer months and lower values of the same during winter months were also recorded by Dewan (1973), Chakrabarty et al. (1959), Banerjea (1967) and Michael (1969). In the present study, the ranges of total alkalinity obtained in pond land in pond 2 were 77.75 to $136.25 \mathrm{ppm}$ and 58.00 to $95.00 \mathrm{ppm}$, respectively, which were within the productive range. Banerjea (1967) reported that $60-70 \%$ of the average to highly productive ponds he investigated had their total alkalinity ranging from $20.00-200.00 \mathrm{ppm}$. Moyle (1946) from a study of large number of lakes and ponds in Minnesota, reported that the ponds and lakes with the range of total alkalinity 0.0 - $20.00 \mathrm{ppm}$ are low productive, 20.00 $40.00 \mathrm{ppm}$ low to medium productive, and 40.00 - $90.00 \mathrm{ppm}$ medium to high productive.

Nitrate-nitrogen $\left(\mathrm{NO}_{3}-\mathrm{N}\right)$ : The highest values of nitrate-nitrogen during summer months might be due to heavy rainfall, because the rain water carried nitrogenous substances into the pond from the surrounding areas and rain also brings some nitrate produced from atmospheric nitrogen as a result of lightening during the rainy season. Roy (1955), Lakshminarayana (1965), David et al. (1969), Sahai and Sinha (1969), 
Munwar (1970), and Islam et al. (1974) obtained higher amount of nitrate after heavy rainfall. Rahman et al. (1982) observed that the range of nitrate-nitrogen was $0.074-0.304 \mathrm{ppm}$.

Phosphate-phosphorus ( $\left.\mathrm{PO}_{4}-\mathrm{P}\right)$ : The higher values of phosphate-phosphorus in summer months (October, March and April) (Table 2) might be due to leaching of it from soil through inflow of water and rainfall. Ganapati ((1942) and Roy (1955) reported that the high amount of phosphate during monsoon was due to its accumulation into the pond carried by rain- washings and produced as a result of decomposition of organic matter. Lakshminarayana (1965), David et al. (1969), Sahai and Sinha (1969) and Islam et al. (1974) also made similar observations. Rahman et al. (1982) observed that the range of phosphatephosphorus was 0.028-0.173 ppm. Ganapati (1942), and Sahai and Sinha (1969) observed the lowest values of phosphate-phosphorus during winter months.

Table 2. Monthly variations of chemical factors of water of the ponds.

\begin{tabular}{|c|c|c|c|c|c|c|c|c|c|c|c|c|}
\hline \multirow[t]{2}{*}{ Month } & \multicolumn{2}{|c|}{ DO ppm } & \multicolumn{2}{|c|}{ Free $\mathrm{CO}_{2} \mathrm{ppm}$} & \multicolumn{2}{|c|}{$\mathrm{pH}$} & \multicolumn{2}{|c|}{ Total alkalinity } & \multicolumn{2}{|c|}{$\mathrm{NO}_{3}-\mathrm{N}$ ppm } & \multicolumn{2}{|c|}{$\mathrm{PO}_{4}-\mathrm{P}$ ppm } \\
\hline & Pond 1 & Pond 2 & Pond 1 & Pond 2 & Pond 1 & Pond 2 & Pond 1 & Pond 2 & Pond 1 & Pond 2 & Pond 1 & Pond 2 \\
\hline Oct & 6.99 & 7.03 & 2.58 & 2.08 & 7.84 & 7.57 & 77.75 & 58.00 & 0.430 & 0.325 & 0.095 & 0.075 \\
\hline Nov & 7.49 & 8.10 & 3.34 & 1.99 & 7.58 & 7.72 & 90.00 & 69.50 & 0.321 & 0.215 & 0.085 & 0.075 \\
\hline Dec & 8.39 & 7.83 & 2.62 & 1.86 & 7.85 & 7.70 & 102.50 & 72.00 & 0.190 & 0.130 & 0.075 & 0.070 \\
\hline Jan & 8.16 & 8.14 & 3.09 & 1.24 & 7.71 & 7.94 & 118.50 & 80.13 & 0.150 & 0.120 & 0.085 & 0.065 \\
\hline Feb & 7.79 & 8.20 & 2.22 & 1.10 & 7.75 & 8.13 & 124.75 & 81.50 & 0.205 & 0.180 & 0.085 & 0.060 \\
\hline Mar & 8.26 & 8.14 & 1.60 & 1.72 & 7.56 & 7.75 & 135.75 & 84.50 & 0.300 & 0.245 & 0.095 & 0.070 \\
\hline Apr & 8.12 & 7.99 & 1.96 & 2.22 & 7.60 & 7.65 & 136.25 & 95.00 & 0.310 & 0.320 & 0.090 & 0.080 \\
\hline Average & 7.88 & 7.96 & 2.49 & 1.74 & 7.70 & 7.78 & 112.14 & 77.23 & 0.270 & 0.219 & 0.087 & 0.07 \\
\hline$\pm \mathrm{SD}$ & \pm 0.46 & \pm 0.41 & \pm 0.58 & \pm 0.39 & \pm 0.12 & \pm 0.18 & +20.98 & \pm 11.03 & \pm 0.089 & \pm 1.077 & \pm 0.0064 & \pm 0.0062 \\
\hline \multicolumn{13}{|l|}{ Range } \\
\hline Pond 1 & & & 1.6 & 09 & & 85 & & 36.25 & 0.15 & .430 & 0.0 & 0.095 \\
\hline Pond 2 & 7.03 & 8.41 & 1.10 & 2.22 & 7.57 & -8.13 & 58.00 & 95.00 & 0.120 & 0.325 & 0.06 & 0.08 \\
\hline
\end{tabular}

\section{Diel changes of water temperature}

The diel changes of temperature of water of pond 1 show that maximum temperature was found at 12 noon on all the 14 days of study of diel change and minimum temperature was found at $12 \mathrm{mid}$ night except on 3 days of study of diel change (March 15th, April 15th, and April 30th) which was at 6 a.m. instead of 12 mid night.

The trend of diel change of temperature as found in pond 1 is that after 12 noon (when temperature was maximum) temperature started to fall upto midnight and on 3 sampling days upto 6 a.m. and then it started to increase again and reached to the maximum level at 12 noon. This is clearly due to the diel changes of solar radiation on the earth. From Table 3 the diel changes of water temperature of pond 2 shows the similar diel changes as those found in pond 1 mentioned above.

\section{Diel variations of chemical factors}

The data of diel variations of chemical factors of two ponds have been shown in Table 3.

Dissolved oxygen: During the study period the maximum values of dissolved oxygen were recorded at 6 p.m. and the minimum values were recorded at 6 a.m. in both the ponds (Table 3 ). The dissolved oxygen content of two ponds was found to increase more or less gradually after 6 a.m. till the highest reached at 6 p.m. and then it decreased until 6 a.m. in both the ponds. The continued increase in dissolved oxygen concentration from 6 a.m. to 6 p.m. was associated to photosynthetic activity of the phytoplankton and its gradual decrease from 6 p.m. to 6 a.m. was due to respiration by the biota and absence of photosynthetic activity. George (1961) reported similar result. Khan et al. (1970) and Dewan (1973) also obtained maximum values at 18:00 hours (6 p.m.) and minimum values at 06:00 hours (6 a.m.). In general, during the winter, months there were high concentrations of oxygen and in the summer months, the concentrations of oxygen were comparatively lower. Higher values of dissolved oxygen in winter and lower values in summer in most cases might be due to the effects of temperature on the solubility of oxygen in water. The solubility of oxygen in water decreases with the rise of water temperature.

Free carbon dioxide: During the study period, the maximum values of free carbon dioxide were recorded at 6 a.m. and the minimum values were recorded at 12 noon in both the ponds. The lower amounts of free carbon dioxide at 12 noon and 6 p.m. and the highest amounts of the same at 6 a.m. (sunrise) can be attributed to the utilization of free carbon dioxide by the processes of photosynthesis during the day which resulted very low or zero amount of free carbon dioxide at 12 noon and 6 p.m. and due to the release of free carbon dioxide by the processes of respiration 
throughout the night when photosynthesis is absent. Again, the free carbon dioxide content was higher during winter months (December and January) than in summer months (March and April). This might be due to shorter duration of photosynthesis and longer period of respiration in winter and vice versa in summer. Dewan (1973) also obtained higher amount of free carbon dioxide during winter months than in summer months. The free carbon dioxide was found to bear an inverse relationship with dissolved oxygen. Dewan (1973) also noted similar relationship in his study.

Hydrogen ion concentration $(\mathrm{pH})$ : During the study period, the maximum values of $\mathrm{pH}$ were recorded at $6 \mathrm{p} . \mathrm{m}$. and the minimum values of $\mathrm{pH}$ were recorded at $6 \mathrm{a} . \mathrm{m}$. in both the ponds. The highest values of $\mathrm{pH}$ at 6 p.m. (evening) and lowest values at 6 a.m. (morning) were most probably associated with the high rate of utilization of free carbon dioxide in photosynthesis throughout the day which resulted in the rise of $\mathrm{pH}$ value at $6 \mathrm{p} . \mathrm{m}$. and with the accumulation of free carbon dioxide as a product of respiration of biota and decomposition of organic matter and also due to absence of photosynthesis at night resulted low value of $\mathrm{pH}$ at 6 a.m. Dewan (1973) reported similar observations in a pond. Atkins and Harris (1924) and Philip (1926) reported similar results of diel changes of pH. Michael (1969) also observed inverse relationship between carbon dioxide and $\mathrm{pH}$. In the present study, the $\mathrm{pH}$ values were always above the neutral point, which indicates that the ponds are in the productive range of $\mathrm{pH}$.

Total alkalinity: Total alkalinity showed wide diel variations than the other chemical factors of the ponds. The amounts of total alkalinity were found to increase steadily in both the ponds from sunrise till the maximum amounts reached at 6 p.m. It then began to decrease till the minimum amount reached at 6 a.m. The increase of total alkalinity was more gradual than its decrease. The comparatively high values of total alkalinity at 6 p.m. and the low values at 6 a.m. might be due to the utilization of free carbon dioxide by photosynthesis throughout which increased total alkalinity at 6 p.m. and on the other hand the liberation of free carbon dioxide by respiration and decomposition throughout the night in absence of photosynthesis resulted an increase in the amount of free carbon dioxide and a decrease in the amount of total alkalinity at 6 a.m. Clarke (1954) stated that more $\mathrm{CaCO}_{3}$ is formed when carbon dioxide is drawn up from water by photosynthesis. The total alkalinity showed direct relationship with $\mathrm{pH}$ and oxygen and inverse relationship with free carbon dioxide. Similar relationships were also observed by Dewan (1973) in a study. Among all the chemical factors, total alkalinity showed the highest ranges of diel variation. Then the dissolved oxygen, free carbon dioxide, and $\mathrm{pH}$ occupied the successive positions with respect to ranges in the diel variations. However, all the chemical factors showed appreciable diel variations throughout the study period which indicate that the ponds are productive.

\section{Plankton}

\section{Phytoplankton}

Chlorophyceae was found dominant with respect to number of genera in both the ponds. Scenedesmus was the most dominant genus in Chlorophyceae in both the ponds and was present throughout the whole study period. Myxophyceae was the next dominant group with respect to number of genera in both the ponds. Bacillariophyceae, Euglenophyceae and Cyanophyceae were less dominant groups with respect to number of genera in both the ponds. The ranges of phytoplankton were 17,160 30,940 cells/ $L$ and 15,080 - 28,080 cells/ $L$ in pond 1 and pond 2, respectively (Table 4). Monthly successions of phytoplankton were found in both the ponds during the study period. Chakrabarty et al. (1959) made a quantitative study on plankton and physico-chemical conditions of the River J amuna and found a close relationship between the physico-chemical factors and the plankton productivity of the river. Lakshminarayana (1965) found that a correlation between phytoplankton periodicity and population maximum with the physico-chemical factors. He also found closer relations of phytoplankton with the physical factors than with the chemical factors.

\section{Zooplankton}

The major groups of zooplankton recorded during the study period were rotifera, cladocera, copepoda and crustacean larvae. Rotifera showed the numerical dominance in both the ponds through the study period. Brachionus was the most dominant genus in Rotifera in both the ponds and was present throughout the study period. Cladocera, copepoda and crustacean larvae were less dominant groups with respect to number of genera in both the ponds. The ranges of densities of zooplankton were 5,460-10,140 cells/ $L$ and 5,720-10,660 cells/L in pond 1 and pond2, respectively. Monthly successions of zooplankton were observed in both the ponds during the study period. The zooplankton population was found to increase gradually till it reached maximum in October and then decreased. 
Table 3. Diurnal variations of limnological factors of the ponds (Pond No.1=P1; Pond No. 2 =P2).

\begin{tabular}{|c|c|c|c|c|c|c|c|c|c|c|c|c|c|c|}
\hline \multirow[t]{2}{*}{$\begin{array}{l}\text { Sampl- } \\
\text { ing } \\
\text { Month }\end{array}$} & \multirow[t]{2}{*}{$\begin{array}{l}\text { Sampling } \\
\text { Time }\end{array}$} & \multicolumn{2}{|c|}{$\begin{array}{c}\text { Water } \\
\text { Temp. } \\
\left({ }^{0} \mathrm{C}\right)\end{array}$} & \multirow[t]{2}{*}{$\begin{array}{c}\text { Air } \\
\text { Temp } \\
\left({ }^{0} \mathrm{C}\right) \\
\end{array}$} & \multicolumn{2}{|c|}{$\begin{array}{c}\text { Trans- } \\
\text { parency } \\
(\mathrm{cm})\end{array}$} & \multicolumn{2}{|c|}{$\begin{array}{c}\mathrm{DO} \\
(\mathrm{ppm})\end{array}$} & \multicolumn{2}{|c|}{$\begin{array}{c}\text { Free } \mathrm{CO}_{2} \\
(\mathrm{ppm})\end{array}$} & \multicolumn{2}{|l|}{$\mathrm{pH}$} & \multicolumn{2}{|c|}{$\begin{array}{l}\text { Total } \\
\text { Alkalinity } \\
\text { (ppm) }\end{array}$} \\
\hline & & $\mathrm{P} 1$ & $\mathrm{P} 2$ & & P1 & P2 & P1 & $\mathrm{P} 2$ & P1 & P2 & P1 & P2 & $\mathrm{P} 1$ & P2 \\
\hline Oct. & 6 a.m. & 28 & 29 & \multirow{4}{*}{28.85} & \multirow{4}{*}{31.50} & \multirow{4}{*}{35.00} & 4.60 & 4.90 & 3.99 & 3.99 & 7.83 & 7.30 & 66 & 48 \\
\hline \multirow[t]{3}{*}{$15^{\text {th }}$} & 12 noon & 29 & 30 & & & & 7.50 & 7.30 & 0.99 & 0.99 & 8.30 & 7.42 & 63 & 54 \\
\hline & 6 p.m. & 29 & 29 & & & & 9.00 & 7.90 & nil & nil & 8.00 & 8.09 & 82 & 58 \\
\hline & 12 midnight & 27 & 28 & & & & 7.20 & 6.86 & 1.93 & 1.93 & 7.85 & 7.53 & 78 & 50 \\
\hline Oct. & 6 a.m. & 25 & 25 & & & & 5.10 & 6.00 & 4.84 & 4.84 & 7.90 & 7.72 & 84 & 64 \\
\hline $29^{\text {th }}$ & 12 noon & 28 & 28 & 28.50 & 34.50 & 36.70 & 7.60 & 7.70 & 2.99 & 1.93 & 7.85 & 7.52 & 74 & 60 \\
\hline & 6 p.m. & 26 & 26 & & & & 8.10 & 8.90 & 1.93 & nil & 8.07 & 7.88 & 95 & 70 \\
\hline & 12 midnight & 25 & 24 & & & & 6.80 & 6.70 & 3.99 & 2.99 & 7.10 & 7.12 & 80 & 60 \\
\hline Nov. & 6 a.m. & 23 & 23 & & & & 6.74 & 6.50 & 3.99 & 2.99 & 7.03 & 6.86 & 90 & 74 \\
\hline $15^{\text {th }}$ & 12 noon & 25 & 25 & 25.30 & 38.88 & 41.88 & 8.22 & 9.00 & 0.99 & nil & 7.83 & 8.10 & 82 & 60 \\
\hline & 6p.m. & 24 & 24 & & & & 8.40 & 10.00 & 1.93 & nil & 7.70 & 8.15 & 100 & 76 \\
\hline & 12 midnight & 23 & 23 & & & & 7.60 & 8.56 & 2.99 & 0.99 & 7.83 & 7.90 & 92 & 80 \\
\hline Nov. & 6 a.m. & 20 & 20 & & & & 6.12 & 7.10 & 5.99 & 3.99 & 7.70 & 7.50 & 78 & 60 \\
\hline 30th & 12 noon & 21 & 22 & 20.45 & 39.80 & 43.00 & 7.36 & 7.50 & 2.99 & 2.99 & 7.60 & 7.45 & 90 & 64 \\
\hline & 6 p.m. & 19 & 20 & & & & 8.00 & 8.34 & 2.99 & 1.93 & 7.75 & 8.02 & 92 & 70 \\
\hline & 12 midnight & 18 & 19 & & & & 7.50 & 7.80 & 4.84 & 2.99 & 7.65 & 7.75 & 96 & 72 \\
\hline Dec. & 6 a.m. & 20 & 19 & & & & 7.00 & 7.00 & 5.99 & 3.99 & 7.45 & 7.40 & 94 & 60 \\
\hline $15^{\text {th }}$ & 12 noon & 21 & 21 & 18.50 & 42.90 & 48.34 & 7.70 & 7.80 & 3.99 & 2.99 & 7.50 & 7.60 & 100 & 68 \\
\hline & 6 p.m. & 19 & 19 & & & & 8.02 & 8.50 & 3.99 & 1.93 & 7.70 & 7.65 & 104 & 70 \\
\hline & 12 midnight & 18 & 19 & & & & 7.50 & 7.55 & 5.98 & 2.99 & 7.56 & 7.55 & 102 & 64 \\
\hline Dec. & 6 a.m. & 19 & 19 & & & & 8.40 & 7.20 & 0.99 & 1.93 & 7.76 & 7.22 & 104 & 78 \\
\hline 30th & 12 noon & 20 & 21 & 19.40 & 44.60 & 50.40 & 9.50 & 8.12 & nil & nil & 8.50 & 8.14 & 108 & 70 \\
\hline & 6 p.m. & 19 & 19 & & & & 10.0 & 8.64 & nil & nil & 8.40 & 8.22 & 110 & 82 \\
\hline & 12 midnight & 18 & 19 & & & & 9.02 & 7.80 & 0.99 & 0.99 & 7.94 & 7.84 & 98 & 84 \\
\hline Jan. & 6 a.m. & 19 & 19 & & & & 7.15 & 7.52 & 3.99 & 2.99 & 7.76 & 8.14 & 106 & 78 \\
\hline $15^{\text {th }}$ & 12 noon & 20 & 21 & 19.85 & 43.87 & 48.00 & 7.95 & 8.20 & 1.93 & 1.93 & 7.10 & 7.32 & 110 & 80 \\
\hline & 6 p.m. & 19 & 19 & & & & 9.05 & 8.90 & 0.99 & nil & 8.25 & 8.20 & 120 & 87 \\
\hline & 12 midnight & 17 & 19 & & & & 7.75 & 7.88 & 2.99 & 0.99 & 7.70 & 7.78 & 114 & 74 \\
\hline Jan. & 6 a.m. & 17 & 17 & & & & 7.67 & 7.84 & 4.84 & 2.99 & 7.72 & 7.90 & 124 & 80 \\
\hline $30^{\text {th }}$ & 12 noon & 20 & 20 & 17.15 & 46.80 & 45.00 & 8.40 & 8.90 & 2.99 & nil & 7.90 & 8.16 & 120 & 74 \\
\hline & 6 p.m. & 19 & 18 & & & & 9.00 & 9.40 & 2.99 & nil & 7.85 & 8.20 & 126 & 82 \\
\hline & 12 midnight & 18 & 18 & & & & 8.30 & 8.65 & 3.99 & 0.99 & 7.40 & 7.80 & 128 & 86 \\
\hline Feb. & 6 a.m. & 22 & 21 & & & & 7.02 & 7.34 & 2.99 & 2.99 & 7.35 & 7.85 & 116 & 78 \\
\hline $15^{\text {th }}$ & 12 noon & 24 & 23 & 22.15 & 42.81 & 45.00 & 7.65 & 8.52 & 1.93 & 1.93 & 7.80 & 7.94 & 122 & 82 \\
\hline & 6 p.m. & 23 & 22 & & & & 8.74 & 9.12 & 0.99 & nil & 7.95 & 8.25 & 124 & 86 \\
\hline & 12 midnight & 21 & 21 & & & & 7.80 & 7.52 & 1.93 & 0.99 & 7.60 & 8.04 & 120 & 80 \\
\hline Feb. & 6 a.m. & 21 & 24 & & & & 7.44 & 7.62 & 3.99 & 1.93 & 7.63 & 8.12 & 128 & 82 \\
\hline $29^{\text {th }}$ & 12 noon & 23 & 26 & 21.90 & 39.69 & 44.12 & 7.80 & 8.56 & 1.93 & nil & 7.73 & 8.32 & 126 & 80 \\
\hline & 6 p.m. & 22 & 26 & & & & 8.24 & 8.82 & 0.99 & nil & 7.92 & 8.44 & 130 & 86 \\
\hline & 12 midnight & 21 & 24 & & & & 7.60 & 8.12 & 2.99 & 0.99 & 8.02 & 8.08 & 132 & 78 \\
\hline March & 6 a.m. & 26 & 26 & & & & 8.00 & 7.54 & 1.93 & 2.99 & 7.32 & 7.94 & 132 & 80 \\
\hline $15^{\text {th }}$ & 12 noon & 29 & 28 & 28.30 & 33.00 & 40.50 & 8.80 & 8.40 & nil & nil & 8.30 & 7.84 & 136 & 86 \\
\hline & 6 p.m. & 28 & 28 & & & & 9.02 & 9.02 & nil & nil & 7.74 & 8.22 & 140 & 88 \\
\hline & 12 midnight & 27 & 26 & & & & 8.20 & 8.08 & 0.99 & 1.93 & 7.56 & 7.96 & 138 & 82 \\
\hline March & 6 a.m. & 28 & 28 & & & & 7.22 & 7.28 & 3.99 & 3.99 & 7.38 & 7.36 & 126 & 88 \\
\hline 30th & 12 noon & 30 & 30 & 26.60 & 36.20 & 39.00 & 8.04 & 8.20 & 1.93 & 1.93 & 7.12 & 7.54 & 132 & 82 \\
\hline & 6p.m. & 30 & 30 & & & & 9.06 & 8.94 & 0.99 & 0.99 & 7.78 & 7.72 & 142 & 90 \\
\hline & 12 midnight & 28 & 28 & & & & 7.66 & 7.68 & 2.99 & 1.93 & 7.42 & 7.45 & 136 & 80 \\
\hline April & 6 a.m. & 28 & 28 & & & & 7.36 & 7.08 & 2.99 & 3.99 & 7.40 & 7.62 & 136 & 84 \\
\hline $15^{\text {th }}$ & 12 noon & 31 & 31 & 30.00 & 35.20 & 39.80 & 8.22 & 8.12 & 1.93 & 2.99 & 7.65 & 7.34 & 132 & 76 \\
\hline & 6 p.m. & 30 & 30 & & & & 9.12 & 8.86 & 0.99 & 0.99 & 7.70 & 8.08 & 140 & 100 \\
\hline & 12 midnight & 29 & 29 & & & & 7.84 & 7.82 & 1.93 & 1.93 & 7.42 & 7.48 & 138 & 92 \\
\hline April & 6 a.m. & 27 & 26 & & & & 7.28 & 7.10 & 2.99 & 2.99 & 7.38 & 7.72 & 132 & 98 \\
\hline 30th & 12 noon & 29 & 28 & 25.80 & 37.00 & 41.50 & 8.18 & 8.64 & 1.93 & 1.93 & 7.66 & 7.68 & 136 & 94 \\
\hline & 6 p.m. & 28 & 27 & & & & 9.04 & 8.92 & 0.99 & 0.99 & 7.86 & 7.84 & 142 & 104 \\
\hline & 12 midnight & 27 & 27 & & & & 7.92 & 7.34 & 1.93 & 1.93 & 7.78 & 7.44 & 134 & 92 \\
\hline
\end{tabular}

Table 4. Monthly variation of phytoplankton and zooplankton concentration of the ponds.

\begin{tabular}{lcccc}
\hline Sampling Month & \multicolumn{2}{c}{$\begin{array}{c}\text { Phytoplankton } \\
\text { (x 103, Cell/litre) }\end{array}$} & \multicolumn{2}{c}{$\begin{array}{c}\text { Zooplankton } \\
\left(\mathrm{x} 10^{3} \text {, Cell/litre) }\right.\end{array}$} \\
\cline { 2 - 5 } & Pond 1 & Pond 2 & Pond 1 & Pond 2 \\
\hline October & 30.94 & 28.08 & 13.52 & 10.66 \\
November & 24.70 & 23.14 & 9.10 & 7.80 \\
December & 21.32 & 15.08 & 6.24 & 5.72 \\
January & 17.16 & 18.46 & 5.46 & 7.02 \\
February & 20.54 & 21.58 & 7.80 & 8.84 \\
March & 28.86 & 27.04 & 9.36 & 9.62 \\
April & 25.22 & 23.92 & 8.32 & 8.06 \\
\hline
\end{tabular}




\section{Conclusion}

All the limnological factors showed appreciable diel variations throughout the study period, which indicate that the ponds are productive.

\section{References}

Atkins, W.R.G. and Harris, G.T. 1924. Seasonal changes in the water and heliplankton of freshwater ponds. Proc. Roy. Soc. Sci. Dublin. 18: 1-21.

Bamforth, S., 1962. Diurnal changes in shallow aquatic habitats. Limnol. Oceanogr. 7: 348353.

Banerjea, S.M. 1967. Water Qualities and soil conditions of fish ponds in some states of India in relation to fish production. Indian J. Fish. 14: 115-144.

Chacko, P.I. and Ganapati, S.V. 1949. Some observation of the Adayer river with special to its hydrographical conditions. Indian Geogr. J . 24: 1-15.

Chakrabarty, R.D., Roy, P. and Singh, S.B. 1959. A quantitative study of the plankton and the physico- chemical conditions of the J amuna at Allahabad in 1954-55. Indian J. Fish. 6(1): 186203.

Clarke, G.L. 1954. Elements of Ecology. J ohn Wiley and Sons. Inc. New York. pp. 259-276.

David, A., Roy, P., Govind, B.V., Rajagopal, K.V. and Banerjee, P.K. 1969. Limnology and fisheries of Tungabhadra Reservoir. Central Inland Fish. Res. Inst. India Bull. 13: 70-83.

Dewan, S. 1973. Investigation into the Ecology of fishes of Mymensingh Lake. Ph.D. Thesis. Department of Aquaculture and Management Faculty of Fisheries. Bangladesh Agricultural University, Mymensingh. 335p.

Dunn, G.I. 1967. Diurnal fluctuation of physicochemical conditions in shallow tropical pond. Limnol. Oceanograph. 12 (1): 151-154.

Ganapati, S.V. 1941. Diurnal variation in dissolved gases, hydrogen ion concentration and some of the important dissolved substances of biological significance in three temporary rock pools in stream bed at mettur dam. Hydrobiologia. 7: 286-303.

Ganapati, S.V. 1942. An ecological study of a garden pond containing abundant zooplankton. Proc. Ind. Acad. Sci. 17: 41-50.

George, G. 1961.Diurnal variation in two shallow pond in Delhi, India. Hydrobiologia. 18: 265273.

Islam, A.K.M.N., Haroon, A.K.Y. and Zaman, K.M. 1974. Limnological studies of the river Buriganga. I. Physical and chemical aspects. Dhaka Univ. Stud. Part B. 22 (2): 99-111.

Khalaf, A.N. and MacDonald, L.J. 1975. Physicochemical conditions in temperature ponds in the New Forest. Hydrobiologia. 47 (2): 301318.

Khan, A., Siddqui, A.Q. and Najir, M. 1970. Diurnal variation in a shallow tropical freshwater pond in Shahjahanpur, U. P. (India). Hydrobiologia. 35: 297-304

Lakshminarayana, J.S.S. 1965. Studies on the phytoplankton at the river Ganges. Varansia, India. Part-II. Hydrobiologia. 25: 119-130.

Michael, R.G. 1967. Diurnal variation in physicochemical factors and zooplankton in the surface layers of three freshwater fish ponds. Indian J. Fish. 13 (1\&2): 48-82.

Michael, R.G. 1969. Seasonal trend in physicochemical factors and plankton of a freshwater fish pond and their role in fish culture. Hydrobiologia. 33 (1): 144-159.

Miller, G.W. and Rabe, F.W. 1969. A limnological comparison of two small Idaho reservoirs. Hydrobiologia. 33 (3-4): 523-546.

Moyle, J .G. 1946. Some indices of lake productivity. Trans. Am. Fish. Soc. 76: 322-334.

Munwar, M. 1970. Limnological studies on freshwater ponds of Hydrabad, India. Hydrobiologia. 36 (1): 105-128.

Needham, J.G. and Needham, P.R. 1962. A guide to the study of fresh water biology. $5^{\text {th }}$ edition, Holden-Day, Inc. San Francisco. 108p.

Pennak, R.W. 1955. A freshwater invertebrates of the United States. Ronald Press, New York. $769 p$.

Philip, C.V. 1926. Diurnal fluctuations in the hydrogen ion activity of a Minnesota lake. Ecol. 81: 73-89.

Prescott, G.W. 1962. Algae of the western Great Lakes Area. Wm, C. Brown Company, Dubuque, Iowa, USA. 946p.

Rahman, M.S. 1992. Water quality management in aquaculture, BRAC Prokashana, 66, Mohakhali, Dhaka, Bangladesh. 84p.

Rahman, M.S., Chowdhury, M.Y., Haque, A.K.M.A. and Haq, M.S. 1982. Limnological studies of four ponds. Bangladesh J. Fish. 2-5 (1-2): 2535.

Reddy, R.K. 1981 Diel variations of certain physicochemical parameters of water in selected aquatic system. Hydrobiologia 85: 201-207.

Roy, H.K. 1955. Plankton ecology of the river Hoogly at Palta West Bengal. Ecol. 36: 169-175.

Sahai, R. and Sinha, A.B. 1969. Investigation on bioecology of inland water of Gorrakhpur (U. P.), India. Hydrobiologia. 34: 433-447.

Sitaramiah, P. 1966. Studies on the ecology of freshwater pond community. Hydrobiologia. 27: 526- 547 .

Sterin, D.B., Atwell, B.H., Marz, E.L. and Vinet, M.J 1968. A summer Limnological study of lake pontachartain, Louciana. Lussiciana Water Resources Res. Inst. Tech. Report No. 3: 1-83.

Sreenivasan, A. 1970. Limnology of tropical impoundments. A comparative study of the major reservoirs in Madras State, India. Hydrobiologia. 36 (3-4): 443-469.

Swingle, H.S. 1957. Relationships of $\mathrm{pH}$ of pond water to their suitability for fish culture. Proc. $9^{\text {th }}$ Pacific Sci. Congr. 10: 72-75.

Vass, K.F. and Sachlan, M. 1953. Limnological studies on diurnal fluctuations in shallow ponds in Indonesia. Verh. Int. Ver. Limnol. 12: 309-319.

Verma, N. 1967. Diurnal variation in a fish pond in Seoni, India. Hydrobiologia. 30 (1-2): 129-137.

Villadolid, D.V., Panganiban, P. and Megia, T.G. 1954. The role of $\mathrm{pH}$ in pond fertilization. Indo-Pacific Fish Coun. Proc. 5 (11): 109-111.

Vyas, L.N. and Kumar, H.D. 1968. Studies on phytoplankton and other algae of Indrasagar Tanks. Udaisagar, India. Hydrobiologia. 31: 421-434.

Ward, H.B. and Whipple, G.C. 1959. Freshwater Biology. John Wiley and Sons Inc. New York. 1248p. 